\title{
Spatial variation of bat diversity between three floodplain- savanna ecosystems of the Colombian Llanos
}

\author{
Darwin M. Morales-Martínez ${ }^{1 *}$, Miguel E. Rodríguez-Posada ${ }^{1}$, Camilo Fernández-Rodríguez ${ }^{1}$, María C. Calderón-Capote ${ }^{1}$ \\ AND Diego R. GutiéRREZ-SANABRIA ${ }^{1}$
}

\begin{abstract}
${ }^{1}$ Fundación Reserva Natural La Palmita, Centro de Investigación, Grupo de investigaciones territoriales para el uso y conservación. Carrera 4 58-59. Bogotá, Colombia. E-mail: dmmoralesm@unal.edu.co (DMMM), director.cientifico@lapalmita.com.co (MERP), rcfernandezr@unal.edu.co (CFR), mccalderonc@gmail.com (MCC), diecolo24@gmail.com (DRGS).

* Corresponding author
\end{abstract}

The ecology of bat assemblages in savanna ecosystems is poorly known. Studies on this subject are scarce in the Colombian Orinoquía; some authors have argued that this region shows a low diversity of bat species relative to other natural regions of Colombia, which contrasts with reports for other Neotropical savannas. In order to broaden the knowledge about bat assemblages in savanna ecosystems in Colombia, we evaluated the alpha (local) and beta (species turnover) diversities in three savanna ecosystems located in Colombian alluvial flood plains of Orinoco Llanos, as compared to other natural regions of Colombia. We sampled bat assemblages across three alluvial floodplain savannas: E1) Mosaic of floodplain savannas and floodplain forests covering less than $20 \%$ of the original area. E2) Dense high forest growing on the flood plains of Whitewater Andean rivers. E3) Aeolian savannas. Mist nets were used in the understory in all cases. We evaluated the representativeness of samples using the Jackknife 1 estimator. The species richness found was compared with the one reported in representative inventories of other natural regions of Colombia. Differences in alpha diversity between the three ecosystems studied were explored by comparing rankabundance curves and three true-diversity values (q0, q1 and q2). Finally, we evaluated the species turnover across ecosystems using the Jaccard similarity index. A total of 50 bat species were recorded at the regional level, and between 32 and 39 species in each of the ecosystems, representing a greater or similar richness vs other natural regions of Colombia. Sampling representativeness was higher than $80 \%$. Although no differences were observed in terms of species richness (q0) between localities, differences were evident in the structure of assemblages (q1, q2). Finally, the species turnover between localities was high, with similarity values between $57 \%$ and $64 \%$. The species richness recorded in the assemblages studied here is similar to that reported for bat assemblages in other natural regions of Colombia, where a higher diversity has been presumed. The differences observed in the structure of abundances of the assemblages studied here may be associated with ecosystem heterogeneity in the Llanos region, characterized by different types of vegetation structure in the various types of forest. In addition, there may be a negative effect of the degree of transformation of natural ecosystems on bat richness and diversity. On the other hand, the high degree of bat species turnover may stem from differences in the composition and structure of riparian forests coupled with the strong seasonality of precipitation in the region, as reported for other Neotropical savannas.

La ecología de los ensamblajes de murciélagos en ecosistemas de sabana es poco conocida. Para el caso de la Orinoquia colombiana los estudios son escasos; sin embargo, algunos autores han afirmado que esta región presenta una baja diversidad de murciélagos respecto a otras regiones naturales de Colombia, lo cual es contrastante con lo que se ha reportado en otras sabanas del Neotrópico. Con el fin de ampliar el conocimiento de los ensamblajes de murciélagos en ecosistemas de sabanas inundables en Colombia, evaluamos la diversidad alfa (local) y la diversidad beta (recambio de especies) en tres ecosistemas de las sabanas aluviales inundables de los Llanos de Colombia y la comparamos con otras regiones naturales de Colombia. Muestreamos los ensamblajes de murciélagos en tres ecosistemas de las sabanas aluviales inundables: E1) Ecosistema de mosaico de sabanas inundables y bosques de la llanura de desborde con coberturas naturales remanentes menores al $20 \%$ de la cobertura original. E2) Ecosistema de bosque alto denso de las llanuras de inundación de ríos andinos de aguas blancas. E3) Ecosistema de sabanas inundables de llanuras eólicas, empleando redes de niebla en el sotobosque. Evaluamos la representatividad del muestreo por medio del estimador Jackknife 1. Comparamos la riqueza de especies encontrada con la reportada en inventarios representativos de otras regiones naturales de Colombia. Para evaluar si existen diferencias en la diversidad alfa entre los tres ecosistemas estudiados comparamos las curvas de rango-abundancia y tres valores de diversidad verdadera (q0, q1 y q2). Finalmente, evaluamos el recambio de especies entre los ecosistemas utilizando el índice de similitud de Jaccard. Registramos un total de 50 especies de murciélagos a escala regional, y entre 32 y 39 especies en los ecosistemas, riqueza mayor o similar a la encontrada en otras regiones naturales de Colombia. La representatividad de todos los muestreos fue superior al $80 \%$. Aunque no encontramos diferencias en términos de riqueza entre las localidades (q0), evidenciamos diferencias en la estructura de los ensamblajes (q1, q2). Por último, el recambio de especies entre las localidades fue alto, con valores de similitud entre el $57 \%$ y el $64 \%$. La riqueza de especies que registramos en los ensamblajes estudiados, es equiparable a la reportada en ensamblajes de murciélagos de otras regiones naturales de Colombia, donde se ha afirmado que presentan una mayor diversidad. Las diferencias que encontramos en la estructura de las abundancias de los ensamblajes estudiados pueden estar asociadas a la heterogeneidad de los ecosistemas de la región de los llanos, con diferentes tipos de estructura de la vegetación en los diferentes tipos de bosque, adicionalmente, puede existir un efecto negativo del grado de transformación de los ecosistemas naturales en la riqueza y diversidad de murciélagos. Por otro lado, los altos valores de recambio de especies pueden deberse a las diferencias en composición y estructura de los bosques de galería y la fuerte estacionalidad de la precipitación de la región como se ha encontrado en otras regiones de sabanas neotropicales.

Key words: Arauca; Casanare; Chiroptera; Orinoco plains; true diversity.

C 2018 Asociación Mexicana de Mastozoología, www.mastozoologiamexicana.org 


\section{Introduction}

Bats are the dominant mammal group in Neotropical lowland ecosystems, representing nearly half of the total number of species (Voss and Emmons 1996; Simmons and Voss 1998; Voss et al. 2001; Lim and Engstrom 2005; Ochoa et al. 2005; Castaño and Corrales 2010). These mammals make up assemblages of a high number of species that supply large amounts of biomass (Lim and Engstrom 2001). In addition, these bats display a great variety of feeding habits that include the use of plant and animal materials in various ways (Findley 1993; Kalko et al. 1996; Schnitzler et al. 2003; Patterson et al. 2003; Saldaña-Vázquez 2014), thus playing key roles in the functioning of ecosystems as regulators of complex ecological processes (Muscarella and Flemming 2007; Kalka et al. 2008; Kunz et al. 2011; Maine and Boyles 2015). Most studies on the ecology of bats in the Neotropics have been conducted in rainforests covering lowlands in the Amazon watershed, Central America and Mexico (Sánchez-Palomino et al. 1993; Voss and Emmons 1996; Montenegro and Romero-Ruiz 1999; Lim and Engstrom 2005; García-García and Santos-Moreno 2008; CalderonPatron et al. 2013). However, the current knowledge about the diversity of bats is scarce in other extensive ecosystems such as the Neotropical savannas (Aguirre 2002).

Neotropical savannas cover more than $3,000,000 \mathrm{~km}^{2}$ distributed in seven regions: the savannas of Central America, the plains ("Llanos") of Colombia and Venezuela, Guyana and the Guiana Shield, the Cerrado, the Llanos de los Moxos, El Pantanal and El Chaco (Sarmiento 1983, 1994). The Llanos of Colombia and Venezuela are one of the most extensive savanna areas in America. In general, there are three types of savannas: piedmont savannas, high-plain savannas, and alluvial floodplain savannas (Sarmiento 1983). The latter occur on depressions between Andean foothills and the Meta River in Colombia, in the Departments of Arauca and Casanare, remaining flooded for nearly eight months during the rainy season due to the accumulation of rainfall that drains very slowly (Sarmiento 1983). The floodplain savanna region is subdivided into several ecosystems such as alluvial savannas and aeolian savannas, introduced pastures and plantations, and a wide strip of riparian forest bordering water courses (Etter 1998; Romero-Ruiz et al. 2010).

In general, bat assemblages in Neotropical savannas display a high species diversity and turnover (Aguirre et al. 2003; Bernard and Fenton 2007; Larrea-Alcazar et al. 2010; Gregorin et al. 2011; Muylaert et al. 2014). It has been argued, however, that bat assemblages in savannas across the natural Colombian Orinoquia region show low species richness and diversity values relative to other types of ecosystems such as tropical rainforests and other natural regions of the country, such as the Amazon and Pacific basins. This is likely caused by a number of factors, namely the seemingly limited carrying capacity of riparian forests; strong climatic fluctuations due to the marked unimodal rainfall pattern with four months of water deficit and eigth months of high precipitation and flooding of a large part of the territory; and vast plains (savannas) that restrain the establishment of trophic assemblages such as foliage-gleaning insectivorous bats (Mantilla-Meluk et al. 2009; Mantilla-Meluk et al. 2014).

However, the diversity of bats in Colombian savanna ecosystems is still underestimated and the current state of knowledge is poor (Ferrer-Perez et al. 2009; Usma and Trujillo 2011). Most studies are limited to inventories of local species and the characterization of alpha diversity (SánchezPalomino et al. 1993; Suarez-Castro and Sánchez-Palomino 2011; Estrada-Villegas and Ramirez, 2013), or to regional lists based on secondary information (Ferrer-Perez et al. 2009; Trujillo et al. 2011; Pardo-Martínez and Rangel-Churio 2014).

Considering that the knowledge of alpha and beta diversity of bat assemblages in savannas of the Colombian Llanos is incipient, and that these comprise several ecosystems. The objectives of this study were the following: 1) characterize the richness and composition of bat assemblages in three ecosystems of alluvial floodplain savannas of Colombia (transformed ecosystems [introduced pastures and plantations], alluvial floodplain savannas along Andean rivers and aeolian savannas). 2) compare the species richness of the study area vs. other natural regions and other types of ecosystems in Colombia. 3) assess any differences in diversity in terms of the structure of assemblages across the three ecosystems studied. 4) evaluate the turnover of bat species among the three ecosystems. We expected a similar richness of bat species in the savanna ecosystems studied relative to other regions of Colombia, a similar species richness and structure of bat assemblages between the areas studied, and a high species turnover at the regional level.

\section{Materials and Methods}

Study Area. The study comprised three floodplain savanna ecosystems in the Departments of Casanare and Arauca, located to the northeast of the Colombian Andes (Figure 1). This region is characterized by a unimodal rainfall pattern with a season of rains and flooding from April to November, followed by a short dry season between December and March (Romero-Ruiz et al. 2010). This region displays two main types of landscapes, alluvial floodplain savannas and aeolian savannas, which contain different habitats influenced by the flooding dynamics, such as permanent and temporary water bodies, firm land savannas, riparian forests associated with temporal streams, and riparian forests associated with Andean rivers (Gossen 1964; Sarmiento 1984 Romero-Ruiz et al. 2010; Mora-Fernández and Borrás-Ulloa 2011). At the floristic level, savannas are characterized by a homogeneous vegetation structure across the distribution range, although with differences in composition (Sarmiento 1983); this contrasts with the forests associated with these savannas, which may vary broadly in structure, floristic composition and phenological rhythms (Lasso et al. 2010).

The three ecosystems sampled are adjacent to one another, but differ in geographic location with respect to the Andes Mountain Range, the influence of Andean riv- 


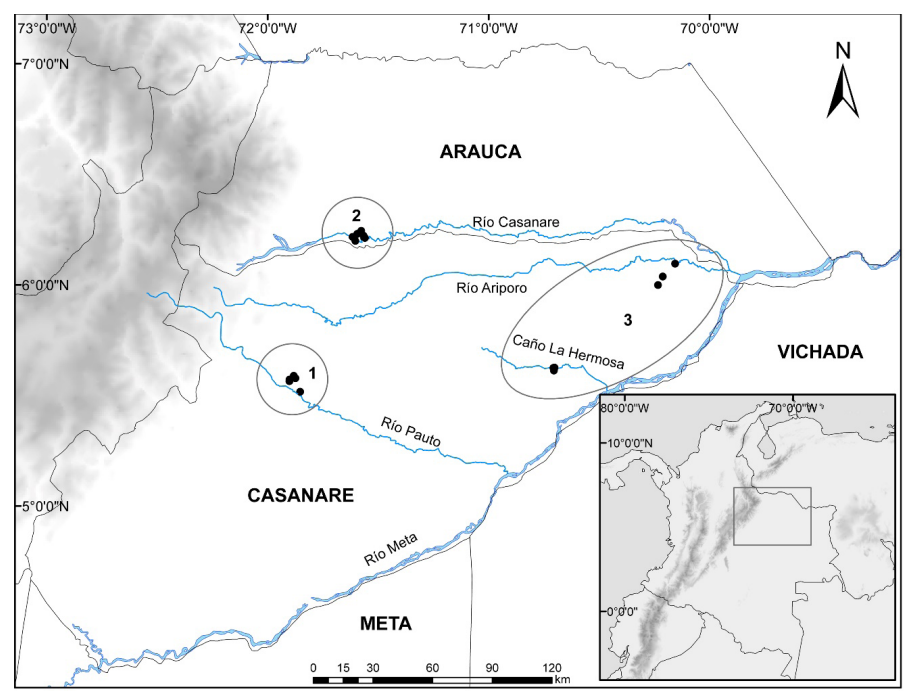

Figure 1. Geographical location of the localities studied in the three ecosystems sampled in the Colombian floodplain savanna: 1. Sampling localities in the mosaic of floodplain savannas and floodplain forests with a remnant cover of less than $20 \%$ of the original natural vegetation (E1). 2. Sampling localities in dense high forest growing on the flood plains of white-water Andean rivers (E2). 3. Sampling localities in floodplain savannas covering aeolian savannas (E3).

ers, and the extent of anthropic intervention by land use. These ecosystems span across extensive relatively uniform areas, with transitional zones not well defined; therefore, to avoid a potential effect on species that can move across the limits of each ecosystem, sampling localities were placed at a distance of $80 \mathrm{~km}$ to $120 \mathrm{~km}$ between them. These are described below:

Ecosystem 1 (E1). Mosaic of floodplain savannas and floodplain forests covering less than $20 \%$ of the original area (Etter 1998). Four localities were sampled, three in the municipality of Pore $\left(5.5646^{\circ},-71.9017^{\circ}, 225 \mathrm{~m} ; 5.5782^{\circ}\right.$, $-71.8744^{\circ}, 180 \mathrm{~m} ; 5.5888^{\circ},-71.8822^{\circ}, 197 \mathrm{~m}$; Figure 1); and one in the municipality of Trinidad $\left(5.5169^{\circ},-71.8535^{\circ}\right.$, 194 m; Figure 1) in the Department of Casanare, located on alluvial floodplain fans of the Pauto River. This ecosystem has been subjected to heavy landscape transformation processes, mostly clearing of riparian forests for crops (improved pastures, oil palm and rice crops), livestock raising, and road and hydrocarbon projects.

Ecosystem 2 (E2). Dense high forest growing on floodplains bordering whitewater Andean rivers (Etter 1998). Two localities were sampled in the municipality of Tame, Department of Arauca $\left(66.2123^{\circ},-71.5607^{\circ}, 201 \mathrm{~m} ; 6.2225^{\circ},-71.5668^{\circ}, 183 \mathrm{~m}\right.$; Figure 1), and two in the municipality of Hato Corozal, Department of Casanare $\left(6.1990^{\circ},-71.6038^{\circ}, 191 \mathrm{~m} ; 6.2169^{\circ},-71.6163^{\circ}\right.$, $171 \mathrm{~m}$; Figure 1) located on alluvial floodplain fans of the Casanare River. The area is still covered by large extensions of riparian forests bordering the Casanare River and natural savannas. It is currently facing landscape transformation processes due to the advance of the agricultural frontier and livestock raising, as well as the oil and gas industry.

Ecosystem 3 (E3). Aeolian savannas (Etter 1998). Four localities were sampled in the municipality of Paz de Ariporo $\left(5.6246^{\circ},-70.7072^{\circ}, 120 \mathrm{~m} ; 5.6257^{\circ},-70.7021^{\circ}, 166 \mathrm{~m}\right.$; $6.0959^{\circ},-70.1561^{\circ}, 95 \mathrm{~m} ; 6.0376^{\circ},-70.2118^{\circ}, 111 \mathrm{~m}$; Figure 1) on the eolic floodplain influenced by the Ariporo and Meta white-water rivers. This is a unique ecosystem that spans along the Meta river west bank, including natural savannas that are used primarily for extensive livestock farming. There are no agriculture, hydrocarbon industry or roads in the area.

Sampling of bats. Considering the unimodal rainfall pattern in the region, we conducted a field trip in each of the three ecosystems in each climate season. Sampling in the dry season took place between 16 March and 16 April 2015, and in the rainy season, between 5 August and 4 September 2015. Sampling was always carried out in riparian forests. Bats were captured using between nine and twelve mist nets per night, each measuring six or nine meters long by $2.5 \mathrm{~m}$ high. Nets were installed at the understory level, keeping them open between 17:30 and 23:00 hours. The total sampling effort was $15,313 \mathrm{~m} /$ net/hour in 56 nights. The sampling effort by type of ecosystem was $5,527 \mathrm{~m} /$ net/hour for E1; 4,935 m/net/hour for E2; and 4,851 m/net/hour for E3.

For each individual bat captured, conventional morphometric data, sex and reproductive status were recorded. We collected at least one specimen of each species identified in the field to confirm the identification and build a baseline collection for the region (Appendix 1). Individuals were handled following the procedures described and illustrated by Kunz et al. (2011). All collected specimens were deposited in the "Alberto Cadena García" Collection of Mammals of the Instituto de Ciencias Naturales at the Universidad Nacional de Colombia (ICN), and in the Collection of Mammals of the Instituto Alexander von Humboldt $(\mathrm{IAvH})$. Individuals that were not collected were temporarily marked on the forearm with nail polish to avoid counting an individual more than once. Specimens were collected under a research license as per Resolution No. 500.41-160883 dated 19 July 2016 granted by CORPORINOQUIA.

Sampling Representativeness. Sampling representativeness was assessed using the Jackknife 1 non-parametric estimator because it involves little bias and a high precision (González-Oreja et al. 2010). A total of 100 randomizations were carried out to avoid the influence of the order of occurrence in the sampling (Soberón and Llorente 1993). Each capture was considered as a separate and random unit of sampling effort (Willott 2001). Based on the maximum richness values estimated by the index, and considering this value as $100 \%$, the relative (\%) representation of species recorded during the field phase was determined (Moreno and Halffter 2000).

Alpha diversity: estimated richness and true diversity measures. The bat species richness was compared between the three ecosystems by means of species accumulation curves extrapolated to the highest capture value across samples (Chao et al. 2014) using the software EstimateS 9.1 (Colwell 2013). The structure of each bat assemblage was described by means of range-abundance curves as suggested by Feinsinger (2004), which were compared using a KolmogorovSmirnov test for two samples in search of significant differences in structure between species assemblages. 
In turn, the structure of abundances between the three ecosystems was compared by means of an analysis of true diversity or effective number of species (Jost 2006; Moreno et al. 2011). Three values of q were used for the analysis of abundance: $q 0$ is insensitive to abundance and determines species richness; q1 (exponential of the Shannon index) assumes that the weight of a particular species is proportional to its abundance in the community; $q 2$ (the inverse of the Simpson index) considers mostly the common species (Moreno et al. 2011). These analyses considered the estimators recommended by Moreno et al. (2011). For q0, we used the non-parametric estimator ACE (Chao and Lee 1992). For $q 1$, an estimator of the Shannon index that does not require a complete knowledge of the community ("Bias-corrected Shannon diversity estimator", Chao and Shen 2003). For q2, the MVUE estimator ("minimum variance unbiased estimator", Chao and Shen, 2010). These analyses were run with the software SPADE (Chao and Shen, 2010).

Beta diversity: species turnover. We evaluated the turnover of bat species across the ecosystems studied using the Jaccard similarity coefficient, since this qualitative index is insensitive to either sample size or species abundance. In addition, a phenogram was built using the unweighted pair-group method (Crisci and Lopez 1983), assuming that the similarity between ecosystem assemblages is low when it falls below $70 \%$.

\section{Results}

Sampling Representativeness. Total of 1,274 individuals were captured, belonging to 50 species from six bat families (Table 1). The sampling representativeness for each ecosystem was above $80 \%$ based on the Jackknife 1 estimator. The ecosystem with the highest species richness observed was E2 with 39 species, which yielded a representativeness of $81.3 \%$ (47.98 spp.), followed by E3 with 37 species and a representativeness of $80.0 \%$ (45.98 spp.), and finally E1 with 32 species and a representativeness of $84.2 \%$ (37.99 spp.), all based on the Jackknife 1 estimator.

Alpha diversity of floodplain savannas relative to other natural regions of Colombia. This work recorded diversity values that were either higher than or similar to those reported for various types of ecosystems in other regions of Colombia, such as rainforests of Chocó (30 species, AsprillaAguilar et al. 2007), and Amazon (44 species, Sánchez-Palomino et al. 1993; 28 species, Polanco-Ochoa et al. 1999; 46 species, Montenegro and Romero-Ruiz 1999), and dry forests of Caribbean (20 species, Vela-Vargas and Perez-Torres 2012; 25 species, Díaz-Pulido et al. 2014; 22 species, Sampedro et al. 2007) and Inter-Andean valleys (19 species, PerezTorres et al. 2009; 42 species, Bejarano-Bonilla et al. 2007; 24 species, García-Herrera et al. 2015; 12 species in Patía and 13 species in Chicamocha, Sánchez et al. 2007; Table 2 ). As regards the number of species in the family Phyllostomidae (33 species) and the subfamily Phyllostominae (sensu Wetterer et al. 2000; Simmons 2005; 13 species). We found values higher than or similar to those reported in the works mentioned above for regions with presumed higher species richness of these taxa (Mantilla-Meluk et al. 2009; Table 2). In Chocó, for instance, 26 species of Phyllostomidae and two species of Phyllostominae have been recorded (Asprilla-Aguilar et al. 2007). In the Amazon, between 25 and 33 species of Phyllostomidae and from 5 to 9 of Phyllostominae (Sánchez-Palomino et al. 1993; Polanco-Ochoa et al. 1999; Table 2). In addition, the percentages of Phyllostominae species (36-40\%; number of species of the subfamily Phyllostominae recorded in each ecosystem relative to the total number of species of the family Phyllostomidae recorded by ecosystem) are higher than those reported for these bats in other natural regions of Colombia (Table 2).

With regard to species diversity of the non-Phyllostomidae families, we recorded a total of 17 species, with a range between 10 and 12 species, by ecosystem sampled. The representativeness of non-phyllostomid bats in the alpha diversity of the whole assemblage was $34 \%$, with a range between $25 \%$ and $32 \%$ by locality (Table 2), which is higher than other regions. For example, in Chocó these bats only accounted for $13.3 \%$, and in the Amazon between 13 and $25 \%$, of all species; however, two assemblages of the Colombian Caribbean and one of the Inter-Andean valleys showed a high percentage of non-phyllostomid bats, between $30 \%$ and $40 \%$ (Table 2).

Alpha diversity by ecosystem. According to the rarefaction curves extrapolated to the greatest number of individuals per sample ( $E 1=492$ individuals), the ecosystems with the highest species richness were E2 and E3, with 40.46 and 39.79 species, respectively, followed by E1 with 32 species (20\% fewer species than the other two locations; Figure 2). The species recorded in E1 belong to four families. The most abundant family is Phyllostomidae with $87.2 \%$ of all individuals captured in E1 (428 ind. captured, 22 species), followed by Emballonuridae with 7.7 \% (38 ind. captured, 5 species), Verpertilionidae with $4.9 \%$ (24 ind. captured, 4 species), and Molossidae with $0.2 \%$ (1 individual captured,

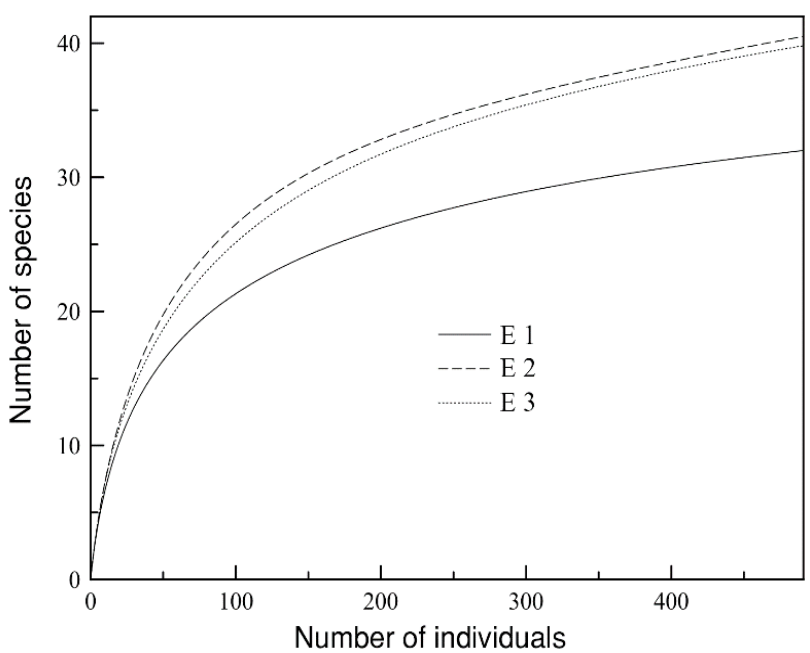

Figure 2. Species accumulation curve extrapolated to 492 individuals of the three ecosystems sampled in the Colombian floodplain savannas: Comparatively, the ecosystem E1 shows a lower estimated species richness relative to the other two ecosystems (E2 and E3). 
Table 1. List of bat species, number of individuals captured, acronyms, and type of ecosystem sampled in the Colombian floodland savannas in Colombia.

\begin{tabular}{|c|c|c|c|c|}
\hline Taxa & Acronym & E1 & E2 & E3 \\
\hline \multicolumn{5}{|c|}{ Emballonuridae } \\
\hline Cyttarops alecto & $\mathrm{Ca}$ & 0 & 3 & 0 \\
\hline Peropteryx macrotis & $\mathrm{Pm}$ & 3 & 0 & 0 \\
\hline Rhynchonycteris naso & Rns & 4 & 4 & 12 \\
\hline Saccopteryx bilineata & $\mathrm{Sccb}$ & 3 & 1 & 3 \\
\hline Saccopteryx canescens & Sccc & 15 & 6 & 6 \\
\hline Saccopteryx leptura & Sccl & 13 & 3 & 5 \\
\hline \multicolumn{5}{|c|}{ Phyllostomidae } \\
\hline \multicolumn{5}{|l|}{ Micronycterinae* } \\
\hline Lampronycteris brachyotis & $\mathrm{Lb}$ & 0 & 1 & 5 \\
\hline Micronycteris megalotis & Mmg & 0 & 3 & 2 \\
\hline Micronycteris microtis & Mmi & 2 & 4 & 1 \\
\hline Micronycteris minuta & $\mathrm{Mmn}$ & 0 & 3 & 2 \\
\hline \multicolumn{5}{|l|}{ Desmodontinae } \\
\hline Desmodus rotundus & $\mathrm{Dr}$ & 45 & 8 & 46 \\
\hline \multicolumn{5}{|l|}{ Phyllostominae* } \\
\hline Gardnerycteris crenulatum & Mc & 1 & 8 & 12 \\
\hline Lophostoma brasiliense & Lph & 6 & 1 & 6 \\
\hline Macrophyllum macrophyllum & $\mathrm{Mmp}$ & 1 & 0 & 0 \\
\hline Phyllostomus discolor & $\mathrm{Pd}$ & 8 & 1 & 0 \\
\hline Phyllostomus elongatus & $\mathrm{Pe}$ & 3 & 14 & 19 \\
\hline Phyllostomus hastatus & Phs & 9 & 6 & 1 \\
\hline Tonatia saurophila & Tsau & 11 & 6 & 3 \\
\hline Trachops cirrhosus & Crrt & 0 & 8 & 13 \\
\hline \multicolumn{5}{|l|}{ Glossophaginae } \\
\hline Choeroniscus minor & $\mathrm{Ch}$ & 0 & 1 & 0 \\
\hline Glossophaga longirostris & $\mathrm{Gl}$ & 0 & 2 & 2 \\
\hline Glossophaga soricina & Gs & 1 & 7 & 1 \\
\hline \multicolumn{5}{|l|}{ Carolliinae } \\
\hline Carollia brevicauda & $\mathrm{Cb}$ & 42 & 99 & 61 \\
\hline Carollia perspicillata & $\mathrm{Cp}$ & 29 & 12 & 4 \\
\hline \multicolumn{5}{|l|}{ Glyphonycterinae* } \\
\hline Trinycteris nicefori & Tri & 0 & 6 & 0 \\
\hline \multicolumn{5}{|l|}{ Rhinophyllinae } \\
\hline Rhinophylla pumilio & Rhp & 0 & 0 & 15 \\
\hline \multicolumn{5}{|l|}{ Stenodermatinae } \\
\hline Artibeus lituratus & The & 24 & 38 & 0 \\
\hline Artibeus planirostris & Ap & 139 & 34 & 53 \\
\hline Chiroderma villosum & $\mathrm{Cv}$ & 0 & 4 & 1 \\
\hline Dermanura bogotensis & $\mathrm{Db}$ & 5 & 1 & 0 \\
\hline Dermanura gnoma & $\mathrm{Dg}$ & 1 & 0 & 5 \\
\hline Mesophylla macconnelli & $\mathrm{Mm}$ & 5 & 14 & 4 \\
\hline Platyrrhinus brachycephalus & $\mathrm{Pbr}$ & 22 & 10 & 18 \\
\hline Platyrrhinus helleri & Phll & 3 & 12 & 1 \\
\hline Sturnira aff. lilium ${ }^{1}$ & SII & 2 & 1 & 0 \\
\hline Uroderma bilobatum & Ubil & 55 & 30 & 8 \\
\hline Uroderma magnirostrum & Umag & 15 & 25 & 1 \\
\hline Vampyressa thyone & Vth & 0 & 5 & 0 \\
\hline Vampyriscus bidens & The VBI & 0 & 0 & 1 \\
\hline
\end{tabular}

\begin{tabular}{|c|c|c|c|c|}
\hline & & & & \\
\hline Noctilio albiventris & $\mathrm{Nal}$ & 0 & 0 & 5 \\
\hline \multirow{2}{*}{ Noctilio leporinus } & Nlp & 0 & 0 & 8 \\
\hline & & & & \\
\hline \multirow[t]{2}{*}{ Thyroptera devivoi } & $\mathrm{Td}$ & 0 & 0 & 1 \\
\hline & & & & \\
\hline Molossops temminckii & Mt & 0 & 0 & 1 \\
\hline \multirow[t]{2}{*}{ Molossus molossus } & Mss & 1 & 0 & 0 \\
\hline & & & & \\
\hline Eptesicus brasiliensis & $\mathrm{Eb}$ & 0 & 1 & 0 \\
\hline Eptesicus diminutus & $\mathrm{Ed}$ & 0 & 0 & 3 \\
\hline Eptesicus furinalis & Ef & 1 & 2 & 2 \\
\hline Myotis nigricans & Mcfn & 11 & 23 & 24 \\
\hline Myotis riparius & $\mathrm{Cffm}$ & 10 & 15 & 6 \\
\hline Rhogeessa io & Rio & 2 & 1 & 0 \\
\hline Total of individuals & & 492 & 421 & 361 \\
\hline Total Number of species & & 32 & 39 & 37 \\
\hline
\end{tabular}

* Subfamilies corresponding to the subfamily Phyllostominae sensu Wetterer et al. (2000) and Simmons (2005) discussed in the text.

${ }^{1}$ Considered as Sturnira aff. lilium, as the nominal species S. lilium was restricted to eastern Brazil and the populations of eastern Colombia have no assigned name (Velazco and Patterson 2013).

1species; Table 1). The most abundant species in E1 were Artibeus planirostris with $28.3 \%$, followed by Uroderma bilobatum with $11.2 \%$, Desmodus rotundus with $9.1 \%$, Carollia brevicauda with $8.5 \%$, and Carollia perspicillata with $5.9 \%$ (Figure 3).

The 39 species reported in E2 belong to three families. The most abundant family was Phyllostomidae with $86 \%$ of all individuals captured in E2 (362 ind. captured, 29 species), followed by Vespertilionidae with $10.0 \%$ (42 ind. captured, 5 species), and Emballonuridae with $4.0 \%$ (17 ind. captured, 5 species). The most abundant species recorded corresponds to Carollia brevicauda with $23.5 \%$, followed by Artibeus lituratus with $9.0 \%$, Artibeus planirostris with $8.1 \%$, Uroderma bilobatum with $7.1 \%$, Uroderma magnirostrum with $5.9 \%$, and Myotis nigricans with $5.5 \%$ of the total number of individuals captured; the remaining species captured account for less than $5.0 \%$ of total captures (Figure 3 ).

The species recorded in E3 are distributed in six families. The most abundant family was Phyllostomidae with $78.9 \%$ of all individuals captured in E3 (285 ind. captured, 25 species), followed by Vespertilionidae with $9.7 \%$ (35 ind. captured, 4 species), Emballonuridae with $7.2 \%$ (26 ind. captured, 4 species), Noctilionidae with $3.6 \%$ (13 ind. captured, 2 species), and Thyropteridae and Molossidae, each with $0.3 \%$ of all individuals captured in E3 and with 1 species in each family. The most abundant species were Carollia brevicauda with $16.9 \%$, followed by Artibeus planirostris with $14.7 \%$, Desmodus rotundus with $12.7 \%$, Myotis nigricans with $6.6 \%$, Phyllostomus elongatus with $5.3 \%$, and Platyrrhinus brachycephalus with $5.0 \%$; the remaining species accounted for less than $5.0 \%$ of total captures (Figure 3 ).

Rank-Abundance curves and true diversity measures. There were no significant differences between the rank- 


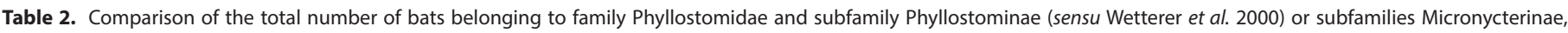

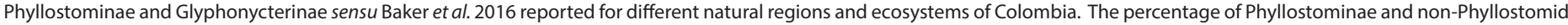
bat species is shown.

\begin{tabular}{|c|c|c|c|c|c|c|c|c|c|c|c|c|c|c|c|c|}
\hline \multirow{2}{*}{$\begin{array}{l}\text { Region or ecosystem } \\
\text { Sources }\end{array}$} & \multirow{2}{*}{$\begin{array}{r}\text { Chocó } \\
1\end{array}$} & \multirow{2}{*}{ Amazon } & \multirow[b]{2}{*}{3} & \multicolumn{3}{|c|}{ Caribbean } & \multicolumn{3}{|c|}{ Andean forests } & \multicolumn{3}{|c|}{ Dry inter-Andean valleys } & \multicolumn{4}{|c|}{$\begin{array}{l}\text { Orinoquia } \\
\text { (floodplain savanna) }\end{array}$} \\
\hline & & & & 4 & 5 & 6 & 7 & 8 & 9 & 10 & 11 & 12 & 13 & E1 & E2 & E3 \\
\hline Total spp. & 30 & 44 & 28 & 46 & 20 & 25 & 22 & 19 & 42 & 24 & 13 & 12 & 50 & 32 & 39 & 37 \\
\hline $\begin{array}{l}\text { Total spp. } \\
\text { Phyllostomidae }\end{array}$ & 26 & 33 & 24 & 40 & 14 & 15 & 17 & 16 & 34 & 16 & 11 & 12 & 33 & 22 & 29 & 25 \\
\hline $\begin{array}{l}\text { Total spp. } \\
\text { Phyllostominae }\end{array}$ & 2 & 9 & 5 & 17 & 3 & 5 & 6 & 2 & 3 & 6 & 2 & 3 & 13 & 8 & 12 & 10 \\
\hline$\%$ Phyllostominae & 7.7 & 27.3 & 20.8 & 42.5 & 21.4 & 33.3 & 35.3 & 12.5 & 8.8 & 37.5 & 18.2 & 25.0 & 39.4 & 36.4 & 41.4 & 40.0 \\
\hline $\begin{array}{l}\text { Total spp. } \\
\text { Non-Phyllostomidae }\end{array}$ & 4 & 11 & 4 & 6 & 6 & 10 & 5 & 3 & 8 & 8 & 2 & 0 & 17 & 10 & 10 & 12 \\
\hline$\%$ Non-Phyllostomidae & 13.3 & 25.0 & 14.3 & 13.0 & 30.0 & 40.0 & 22.7 & 15.8 & 19.0 & 33.3 & 15.4 & 0.0 & 34.0 & 31.3 & 25.6 & 32.4 \\
\hline
\end{tabular}

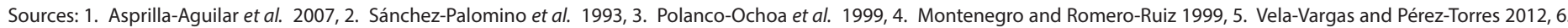

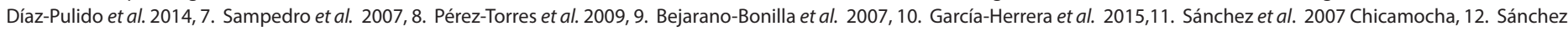
et al. 2007 Patía, 13. This study, E1, E2, E3.

abundance curves of the bat assemblages in the ecosystems studied (E1 y E2: $\mathrm{D}=0.157, P>0.05$; $\mathrm{E} 1$ and E3: $\mathrm{D}=$ $0.118, P>0.05$; E2 and E3: $\mathrm{D}=0.078, P>0.05)$. As regards true diversity, although the richness observed (32 spp.) and the richness calculated by the Jackknife 1 estimator (38 spp.) for E1 are lower vs. E2 and E3, the q0 confidence intervals overlapped ( $\mathrm{E} 1 \mathrm{q} 0=36.8[33.2,51.6]$; $\mathrm{E} 2 \mathrm{q} 0=45.1$ $[40.7,60.7]$; E3 q0 $=43.1$ [38.7, 59.0]); therefore, there are no differences in bat species richness (Figure 4).

In terms of the structure of abundances, we found a higher dominance, ranging between $26 \%$ and $28 \%$, in E1 ( $q 1=1456$ $[12.98,16.15])$ vs. E2 (q1 = $19.96[17.46,22.45])$ and E3 (q1 = 19.44 [16.85, 22.04]) (Figure 4). In addition, E1 showed a lower evenness with respect to the abundances of the common species, ranging between $26 \%$ and $31 \%$ (q2 $=8.26[7.79,8.73]$ ), vs. E2 (11.16 [10.69, 11.65]) and E3 (11.83 [11.54, 12.13]) (Figure 4). These findings suggest that despite the apparent similarity of the range-abundance curves, the structure differs in terms of the number and relative abundances of common and rare species (Figure 3), as shown by q1 and q2 (Figure 4), with E2 and E3 being more diverse than $\mathrm{E} 1$.

Beta diversity: species turnover. We found a high percentage of species turnover (low similarity): E3 displayed the most dissimilar assemblage, with $57 \%$ similarity vs E1 and E2, which in turn showed a $64 \%$ similarity between them (Figure 5).

\section{Discussion}

Our results show, contrary to Mantilla-Meluk et al. (2009, 2014), that bat assemblages in floodplain savanna ecosystems may be as least as or more diverse as in other natural regions of Colombia, and that this diversity may be influenced by the heterogeneity of these natural ecosystems, and be reduced by anthropogenic transformation processes. On the other hand, the species richness and abundance of bats are probably higher than in other Neotropical savannas. For example, in a study in El Cerrado (Oliveira et al. 2017), the sampling effort was twice the one in this work, but recorded half of the species, and captured one third of individuals captured vs this study.

The species richness values observed in this study are similar to or higher than those reported for other natural regions of Colombia considered as of higher richness, such as El Chocó biogeographical region, the Amazon watershed, the Caribbean, and the Inter-Andean valleys. Contrary to Mantilla-Meluk et al. (2009, 2014), bat diversity in the Orinoquia is high relative to other natural regions of Colombia, being one of the areas with the highest bat diversity in the country.

Previously, Mantilla-Meluk et al. (2009) reported a low diversity of the family Phyllostomidae in the Orinoco region relative to other natural regions of Colombia, arguing a supposed absence of stratified forests, a limited carrying capacity of riparian forests, and extreme climatic fluctuations of savanna ecosystems; particularly, these authors noted that large open areas prevent the settlement of a number of foliage-gleaning insectivorous species (subfamily Phyllostominae sensu Wetterer et al. 2000; Simmons 2005). This

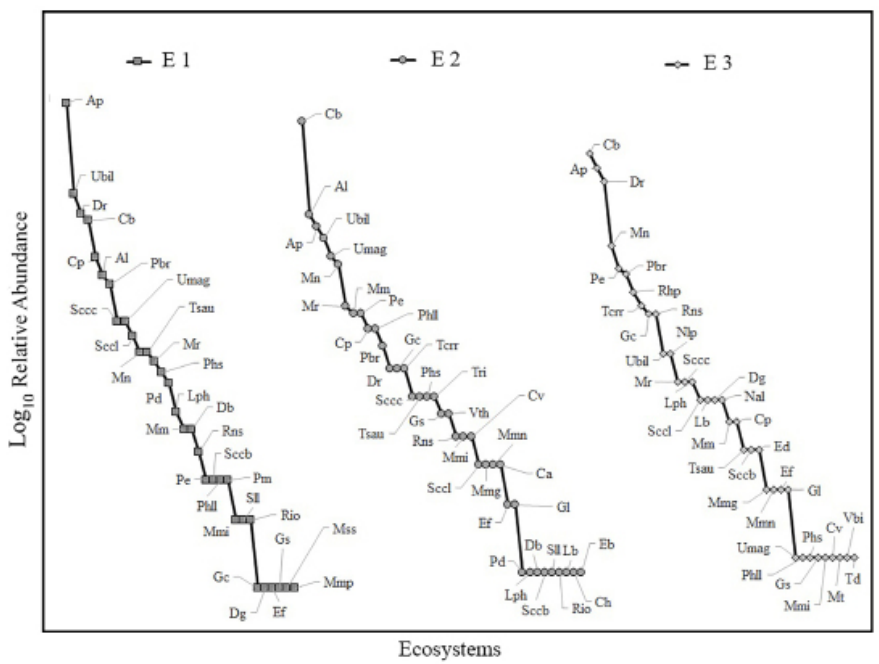

Figure 3. Rank-abundance curves for the three ecosystems sampled in the Colombian floodplain savannas. E1 vs E2 $D=0.157, P>0.05$; $E 1$ vs E3 $\mathrm{D}=0.118 P>0.05$; E2 vs E3 $D=0.078 P>0.05$. Species acronyms are listed in Table 1 . 

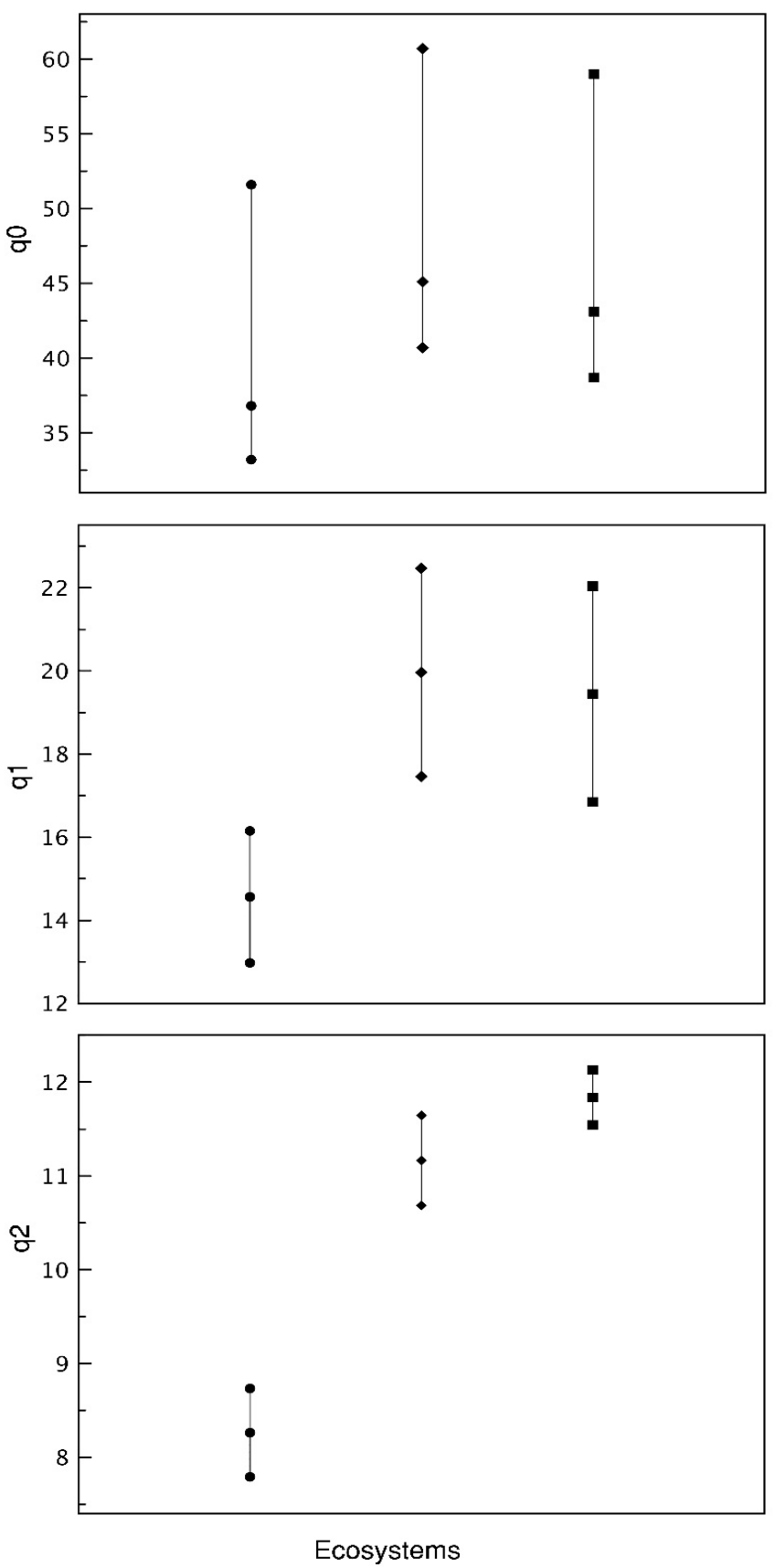

Figure 4. True diversity values measured for the three ecosystems sampled in the Colombian floodplain savannas. Circles: E1. Diamonds: E2. Square: E3. q0 = species richness; $q 1=$ exponential of the Shannon index; $q 2$ = inverse of the Simpson index. According to the confidence intervals, E1 stands out for showing lower q1 and q2 diversity values.

study reports species diversity values for the family Phyllostomidae and the subfamily Phyllostominae that are higher vs. assemblages living in multistratified forests subjected to less marked climatic fluctuations. On the other hand, there is no information about carrying capacity for the various types of ecosystems in different regions. However, our findings show that, if it is hypothesized that multistratified forests (greater vertical stratification) such as the humid forests of the Amazon and the Chocó have a higher carrying capacity vs riparian forests of flooded savanna region, the carrying capacity would not be a limiting factor for bat species richness.
For the savannas of the Brazilian Cerrado, the presence of water courses and the complex vertical structure of riparian forests have been found to be key for the maintenance and conservation of bat diversity, serving as biological corridors and providing shelter, food and water (Redford and Fonseca 1986; Lima et. al. 2017). Our results show that riparian forests in the savanna are home to bat assemblages that are even more diverse than those in Cerrado savannas (Lima et. al. 2017).

Aerial insectivores of the families Emballonuridae and Vespertilionidae showed high richness and abundance in savanna bat assemblages across the ecosystems studied. High abundance for these guilds has been reported in Bolivian floodplain savannas where these may represent up to $40 \%$ of the total number of species captured (Aguirre et al. 2003). Therefore, these insectivores may play a key role in the configuration of bat assemblages in the forest understory of floodplain savannas relative to assemblages in other biogeographic regions.

Alpha diversity: true diversity measures. At the regional level, bat assemblages in floodplain savannas show a similar richness across the three ecosystems studied; yet, these differ in terms of species composition and structure. Various hypotheses have proposed that the diversity of bats in floodplain savannas is directly associated with a precipitation gradient that decreases from the eastern slope of the Andes toward the eastern border of savannas along the Meta River (Estrada-Villegas and Ramirez 2013). However, our results indicate that the diversity of bats does not confirm this trend. E1 - the location nearest to the Andes Mountain Range - showed the lowest estimated diversity, while E2, adjacent to the Andes, and E3, on the eastern portion of floodplain savannas, display a similar diversity. Therefore, bat diversity may be more closely associated with the local structure of the natural vegetation and its degree of transformation.

In terms of the structure of the abundances of bat species across the ecosystems studied, we found that E1 shows a high dominance by a few species compared with E2 and E3. It has been found that bat assemblages show a low resilience to habitat loss in Cerrado savannas, where a drop in richness and diversity levels has been observed (Muylaert et al. 2016). Despite the conflicting results about the effect of deforestation on the reduction of forest cover, habitat loss and transformation, and fragmentation in bat diversity (Coutinho and Bernard 2012), it has been found that the structure of bat assemblages may be dominated by a smaller number of species in areas showing a higher deforestation rate (Fenton et al. 1992; Reis and Müller 1995; Brosset et al. 1996; Cosson et al. 1999; Faria 2006).

In general, savannas in the Colombian Orinoco plains show the highest deforestation rates, with a total reduction of 1,636 km² between 2001 and 2010. The highest forest loss was observed in the interior of the Department in the municipalities of Trinidad and San Luis de Palenque, with a reduction of forest cover of about $27 \%$ in the same period, associated with significant population growth, development of oil extrac- 


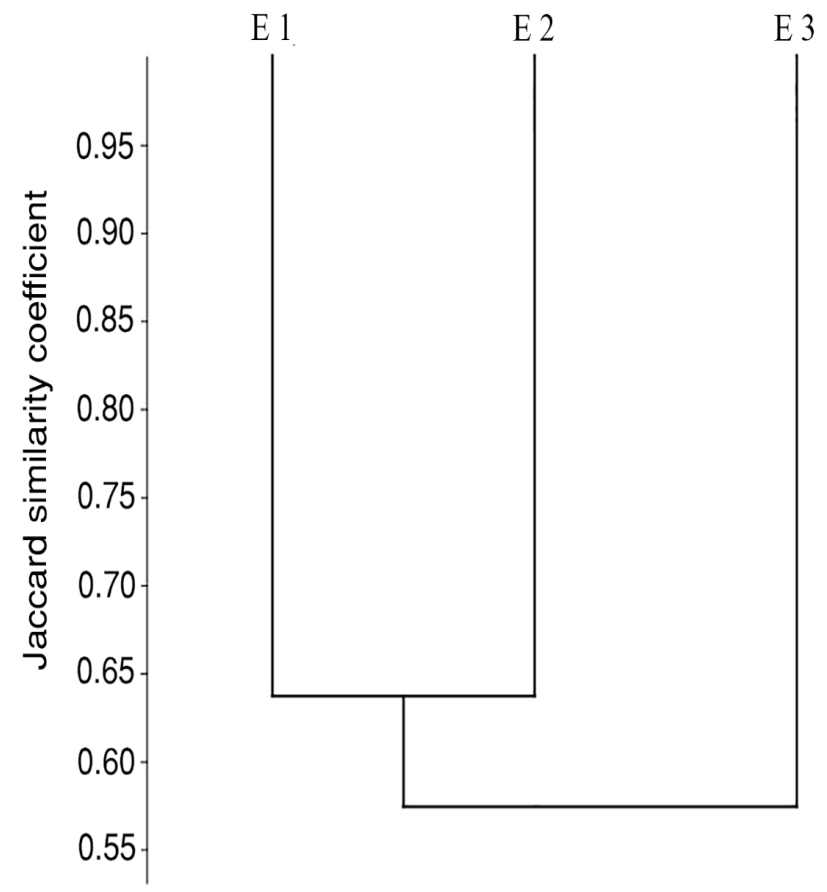

Figure 5. Similarity phenogram (Jaccard coefficient) of ecosystems compared in the Colombian floodplain savannas. The similarity between localities is low, from approximately $70 \%$.

tion infrastructure and intensification of agriculture (SánchezCuervo et al. 2012). Most of the E1 localities sampled belong or are adjacent to the municipality of Trinidad, where remnants of natural vegetation represent less than $20 \%$ of the original area (Etter 1998).

These high rates of deforestation and/or habitat transformation may account for the differences in structure of the abundances of bats, showing a lower diversity in E1 relative to E2 and E3, where there are relative minor impacts on natural ecosystems. This suggests that a higher deforestation rate in floodplain savanna ecosystems coupled with multiple anthropogenic pressures can substantially reduce the diversity of bat assemblages.

Beta diversity: species turnover. We found that savanna bat assemblages show a high species turnover; this high heterogeneity supports a high diversity of species at a regional scale. We consider that this low similarity may be due to the differences in floristic composition and structure at the local level, coupled with the marked seasonality in the region.

In the first case, it has been found that riparian forests located in the Colombian Orinoquia show significant differences in the structure and composition of trees, and their similarity is explained by the geographical distance between forests rather than by the type of habitat (Trujillo and Hainaut-Cárdenas 2018). This could explain why, although all the ecosystems studied are influenced by rivers of Andean origin, marked differences in the composition of their assemblages are evident.

On the other hand, Mantilla-Meluk et al. (2009) and Estrada-Villegas and Ramirez (2013) have proposed that the high seasonality and the decreased rainfall limit the diver- sity of bats in Orinoquía ecosystems. However, the high species turnover found in this study could be explained by the precipitation patterns, as in the case of the Bolivian savannas, where the composition of each bat assemblage changes after each climate cycle (Aguirre et al. 2003). These precipitation patterns may lead to an increased diversity of bats at the regional level.

The Orinoquia is commonly described as the region with the lowest diversity of mammals in Colombia (Alberico et al. 2000; Rodríguez-Mahecha et al. 2005). However, recent studies have shown that the diversity in this region may be similar to that in other regions of Colombia, including Chocó biogeographical region and the Caribbean (Pardo-Martínez and Rangel-Churio 2014), which is supported by our results. This information is key because the region is currently subject to strong anthropogenic pressures in general, including traditional livestock systems, oil extraction processes, and monoculture tree plantations that have led to high conversion rates of natural ecosystems (Andrade 2011), which are likely to increase since the aim is to make of this region the agricultural frontier of Colombia (DPN 2016).

\section{Acknowledgments}

Thanks mainly to the local inhabitants, researchers and owners of the land where the field phase of this study was conducted. The data reported here were obtained as part of the cooperation agreement No. 15-14-172-010EC "Conservation of threatened species in the area of influence of the Bicentennial oil pipeline" between the Instituto de Investigación en Recursos Biológicos Alexander von Humboldt and Fundación Reserva Natural La Palmita, Research Center, and the Agreement \#1918 of 2014 between the government of Casanare and the Consorcio Casanare Biodiversa. We are also grateful to the curators of the collections of mammals of the Institute of Natural Sciences at the National University of Colombia and the Instituto de Investigación en Recursos Biológicos Alexander von Humboldt. The comments of three anonymous reviewers improved the quality of this manuscript. María Elena Sánchez-Salazar translated the manuscript into English.

\section{Literature cited}

AguiRre, L. F. 2002. Structure of a Neotropical savanna bat community. Journal of Mammalogy 83:775-784.

Aguirre, L. F., L. Lenst, R. van Dammet, y E. Matthysent. 2003. Consistency and variation in the bat assemblages inhabiting two forest islands within a neotropical savanna in Bolivia. Journal of Tropical Ecology 19:367-374.

Alberico, M., A. Cadena, J. Hernández-Camacho, and Y. Muñoz-Saba. 2000. Mamíferos (Synapsida: Theria) de Colombia. Biota Colombiana 1:43-75.

AnDRADE, M. G. 2011. Estado del conocimiento de la biodiversidad en Colombia y sus amenazas. Consideraciones para fortalecer la interacción ambiente-política. Revista de la Academia Colombiana de Ciencias Exactas, Físicas y Naturales 35:491-507. 
Asprilla-Aguilar, A. A., H. Mantilla-Meluk, and A. M. JiménezOrtega. 2007. Analysis of the non-hematophagous bat species captured within the plan of eradication of Desmodus rotundus (I. Geoffroyi, 1810) in the Colombian Biogeographic Chocó. Revista Institucional Universidad Tecnológica del Chocó Diego Luis Córdoba 26:42-48.

Baker, R. J., S. Solari, A. Cirranello, and N. B. Simmons. 2016. Higher Level Classification of Phyllostomid Bats with a Summary of DNA Synapomorphies. Acta Chiropterologica 18:1-38.

Bejarano-Bonilla, D. A., A. Yate-Rivas, and M. H. Bernal-Bautista. 2007. Diversidad y distribución de la fauna quiróptera en un transecto altitudinal en el Departamento del Tolima, Colombia. Caldasia 29:297-308.

Bernard, E., and M. B. Fenton. 2007. Bats in a fragmented landscape: Species composition, diversity and habitat interactions in savannas of Santarém, Central Amazonia, Brazil. Biological Conservation 134:332-343.

Brosset, A., P. Charles-Dominique, A. Cockle, J. F. Cosson, and D. MASSON. 1996. Bat communities and deforestation in French Guiana. Canadian Journal of Zoology 74:1974-1982.

Calderón-Patrón, J. M., M. Briones-Salas, and C. E. Moreno. 2013. Diversidad de murciélagos en cuatro tipos de bosque de la Sierra Norte de Oaxaca, México. Therya 4:121-137.

Castaño, J. H., and J. D. Corrales. 2010. Mamíferos de la Cuenca del Río La Miel (Caldas): diversidad y uso cultural. Boletín Científico. Centro de Museos. Museo de Historia Natural 14:56-75.

ChAO, A., AND S. M. LeE. 1992. Estimating the number of classes via sample coverage. Journal of the American Statistical Association 87:210-217.

ChAO, A., AND T. J. SHEN. 2003. Nonparametric estimation of Shannon's index of diversity when there are unseen species in sample. Environmental and Ecological Statistics 10:429-433.

CHAO, A., ANDT.J.SHEN. 2010. SPADE (Species prediction and diversity estimation) v6 Program distributed by the author. Institute of Statistics. National Tsing Hua University. HsinChu, Taiwan.

Chao, A., N. J. Gotelli, T. C. Hsieh, E. L. Sander, K. H. MA, R. K. Colwell, AND A. M. ElLISON. 2014. Rarefaction and extrapolation with Hill numbers: a framework for sampling and estimation in species diversity studies. Ecological Monographs 84:45-67.

Colwell, R. K. 2013. EstimateS: Statistitcal Estimation of Species Richness and Shared Species from Samples (Software), Version 9.1. Disponible en línea: http://viceroy.colorado.edu/ estimates/

Cosson, J. F., J. M. Pons, And D. Masson. 1999. Effects of forest fragmentation on frugivorous and nectarivorous bats in French Guiana. Journal of Tropical Ecology 15:515-534.

Coutinho, G., And E. Bernard. 2012. Neotropical Bats as Indicators of Environmental disturbance: What is the Emerging Message? Acta Chiropterologica 14:143-151.

CRISCI, J. V., AND M. F. LóPEZ. 1983. Introducción a la teoría y práctica de la taxonomía numérica. Serie de Biología. Monografía 26 OEA (Organización de los Estados Americanos). Washington, U. S. A.

Díaz-Pulido, A., A. Benítez, D. A. Gómez-Ruiz, C. A. CalderónAcevedo, A. Link, A. Pardo, F. Forero, A. G. De Luna, E. Payán, and S. Solari. 2014. Mamíferos del bosque seco, una mirada al Caribe colombiano. Pp. 128-165 en El bosque seco tropical en Colombia (Pizano, C., and H. García, eds.). Instituto de Investigación de Recursos Biológicos Alexander Von Humboldt. Bogotá, Colombia.
DPN (Departamento Nacional de Planeación). 2016. Plan maestro de la Orinoquía. Consultado el 18 de julio de 2017. Disponible en línea: www.dnp.gov.co

Estrada-Villegas, S., and B. H. RamíreZ. 2013. Bats of Casanare, Colombia. Chiroptera Neotropical 19:1-13.

EtTer, A. 1998. Mapa general de ecosistemas de Colombia. En Informe Nacional sobre el estado de la biodiversidad en Colombia - 1997 (Chaves M. E., and N. Arango, eds.). Instituto Alexander von Humboldt. Bogotá, Colombia.

FARIA, D. 2006. Phyllostomid bats of a fragmented landscape in the North-Eastern Atlantic forest, Brazil. Journal of Tropical Ecology 22:531-542.

Feinsinger, P. 2004. Diseño de estudios de campo para la conservación de la biodiversidad. FAN (Fundación Amigos de la Naturaleza). Santa Cruz de la Sierra, Bolivia.

Fenton, M. B., L. Acharya, D. Audet, M. B. C. Hickey, C. Merriman, AND M. K. OBRIS. 1992. Phyllostomid bats (Chiroptera: Phyllostomidae) as indicators of habitat disruption in the Neotropics. Biotropica 24:440-446.

Ferrer-Pérez, A., M. Beltrán, A. P. Díaz-Pulido, F. Trujillo, H. MantillaMeluk, O. Herrera, A. F. Alfonso, and E. Payán. 2009. Lista de los mamíferos de la cuenca del Río Orinoco. Biota Colombiana 10:179-207.

FindLEY, J. S. 1993. Bats: a community perspective. Cambridge University Press. Cambridge, United Kingdom.

García-García, J. L., and J. A. Santos-Moreno. 2008. Diversidad de cuatro ensamblajes de murciélagos en San Miguel Chimalapa, Oaxaca, México. Pp. 411-426 in Avances en el estudio de los mamíferos de México II (Lorenzo, C., E. Espinoza, and J. Ortega, eds.). Publicaciones especiales volumen II. Asociación Mexicana de Mastozoología, A. C. Ciudad de México, México.

García-Herrera, L. V., L. A. Ramírez-Fráncel, and G. Reinoso-Flórez. 2015. Mamíferos en relictos de bosque seco tropical del Tolima, Colombia. Mastozoología Neotropical 22:11-21.

González-Oreja, J. A., A. A. de la Fuente-Díaz-Ordaz, L. HernándezSantín, D. Buzo-Franco, and C. Bonache-Regidor. 2010. Evaluación de estimadores no paramétricos de la riqueza de especies. Un ejemplo con aves en áreas verdes de la ciudad de Puebla, México. Animal Biodiversity and Conservation 33:31-45.

Gossen, D. 1964. Geomorfología de los Llanos Orientales. La Revista de la Academia Colombiana de Ciencias Exactas, Físicas y Naturales 12:129-140.

Gregorín, R., E. Gonçalves, C. Cotrim, and A. P. Carmignotto. 2011. Morcegos (Mammalia: Chiroptera) da Estação Ecológica Serra Geral do Tocantins: composição específica e considerações taxonómicas. Biota Neotropical 11:299-311.

Jost, L. 2006. Entropy and diversity. Oikos 113:363-375.

Kalka, M., A. R. Smith, And E. K. V. Kalko. 2008. Bats Limit Arthropods and Herbivory in a Tropical Forest. Science 320:71.

Kalko, E. K. V., O. Handley Charles, and D. Handley. 1996. Organization, Diversity, and Long-Term Dynamics of a Neotropical Bat Community. Pp. 503-553 in Long-term studies in vertebrate communities (Cody, M., and J. Smallwood, eds.). Los Angeles Academic Press. Los Angeles, U. S. A.

Kunz, T. H., E. Braun de Torrez, D. Bauer, T. Lobova, and T. H. Fleming. 2011. Ecosystem services provided by bats. Annals of the New York Academy of Sciences 1223:1-38.

Larrea-Alcázar, D. M., D. Embert, L. F. Aguirre, B. Ríos-Uzeda, M. 
QuintANILLA, AND A. VARGAS. 2010. Spatial patterns of biological diversity in a Neotropical lowland savanna of northeastern Bolivia. Biodiversity and Conservation 20:1167-1182.

Lasso, C. A., J. S. Usma, F. TRUJILLo, AND A. Rial. 2010. Biodiversidad de la cuenca del Orinoco: bases científicas para la identificación de áreas prioritarias para la conservación y uso sostenible de la biodiversidad. Instituto de Investigación de Recursos Biológicos Alexander von Humboldt, WWF Colombia, Fundación Omacha, Fundación La Salle e Instituto de Estudios de la Orinoquia (Universidad Nacional de Colombia). Bogotá, Colombia.

LIM, B. K., AND M. D. ENGSTROM. 2001. Bat community structure at Iwokrama Forest, Guyana. Journal of Tropical Ecology 17:647-665.

LIM, B. K., AND M. D. ENGSTROM. 2005. Mammals of Iwokrama forest. Proceedings of the Academy of Natural Sciences of Philadelphia 154:71-108.

Lima, C.S., L. H. VarzinczaK, and F. C. Passos. 2017. Richness, diversity and abundance of bats from a savanna landscape in central Brazil. Mammalia 81:33-40.

MAINE, J. J., AND J. G. BoYLES. 2015. Bats initiative vital agroecological interactions in corn. Proceedings of national Academy of Sciences 112:12438-12443.

Mantilla-Meluk, H., A. M. Jiménez-Ortega, and R. J. Baker. 2009. Phyllostomid bats of Colombia: annotated chekclist, ditribution, and biogeography. Special Publications, Museum of Texas Tech University 56:1-44.

Mantilla-Meluk, H., H. E. Ramírez-Chaves, A. M. Jiménez-Ortega, and M. E. Rodriguez-PosAdA. 2014. Emballonurid bats from Colombia: Annoted checklist, distribution, and biogeography. Therya 5:229-255.

Montenegro, O., And M. R. Romero-Ruiz. 1999. Murciélagos del sector sur de la Serranía de Chiribiquete, Caquetá, Colombia. Revista de la Academia Colombiana de Ciencias 23:641-649.

Mora-Fernández, C., and M. Borrás-Ulloa. 2011. Propuesta de un área Ramsar en las Sabanas Inundables del Departamento de Casanare-Colombia aplicando herramientas de Sistemas de Información Geográfica. Tesis de Grado. Especialización en Sistemas de Información Geográfica. Centro de Investigaciones en Información Geográfica (CIAF) del Instituto Geográfico Agustín Codazzi (IGAC). Bogotá, Colombia.

Moreno, C. E., AND G. HalfFTer. 2000. Assessing the completeness of bat biodiversity inventories using species accumulation curves. Journal of Applied Ecology 37:149-158.

Moreno, C. E., F. Barragán, E. Pineda, and N. P. Pavón. 2011. Reanálisis de la diversidad alfa: alternativas para interpretar y comparar información sobre comunidades ecológicas. Revista Mexicana de Biodiversidad 82:1249-1261.

Muscarella, R., AND T. H. Flemming. 2007. The role of Frugivorous bats in tropical succession. Biological Review 82:573-590.

Muylaert, R. L., R. Chaves, L. Hortencl, J. Ramos, P. Kerches, and M. A. Ribeiro. 2014. Bats (Mammalia: Chiroptera) in a Cerrado landscape in São Carlos, southeastern Brazil. Checklist 10:287-291.

Muylaert, R. L., R. D. Stevens, and M. C. Ribeiro. 2016. Threshold effect of habitat loss on bat richness in Cerrado-forest landscapes. Ecological Applications 26:1854-1867.
Ochoa G., J., M. Bevilacqua, and F. García. 2005. Evaluación ecológica rápida de las comunidades de mamíferos en cinco localidades del Delta del Orinoco, Venezuela. Interciencia 30:466-475.

Oliveira, H. F. M., N. F. de Camargo, Y. Gager, and L. M. S. Aguiar. 2017. The response of bats (Mammalia: Chiroptera) to habitat modification in a Neotropical savanna. Tropical Conservation Science 10:1-14.

Pardo-Martínez, A., and O. J. Rangel-Churio. 2014. Mamíferos de la Orinoquía colombiana. Pp. 747-784 in Colombia Diversidad Biótica XIV: La región de la Orinoquia de Colombia (RangelChurio, O. J., ed.). Universidad Nacional de Colombia. Bogotá, Colombia.

Patterson, B. D., M. R. Willing, and R. D. Stevens. 2003. Trophic strategies, niche partitioning and patterns of ecological organization. Pp. 536-579 in Bat Ecology (Kunz T. H., and M. B. Fenton, eds.). University of Chicago Press. Chicago, U. S. A. Pérez-Torres, J., C. Sánchez-Lalinde, and N. Cortés-Delgado. 2009. Murciélagos asociados a sistemas naturales y transformados en la ecorregión del eje cafetero. Pp. 157-167 en Valoración de la biodiversidad en la Ecorregión del Eje Cafetero (Rodríguez-Camargo, J. M., J. C. Niño, J. Pineda, A. M. Arias, L. M. Echeverry, M. A. Miranda, and C. L. Ortiz, eds.). Ciebreg. Pereira, Colombia.

Polanco-OchoA, R., V. Jaimes, and W. PiRagua. 1999. Los mamíferos del parque nacional natural la Paya, Amazonia Colombiana. Revista de la Academia Colombiana de Ciencias Exactas, Físicas y Naturales 23:671-682.

REDFORD, K. H., AND G. A. B. FonseCA. 1986. The role of gallery forests in the zoogeography of the Cerrado's non-volant mammalian fauna. Biotropica 18:126-135.

REIS, N., AND M. MuLLER. 1995. Bat diversity of forest and open areas in a subtropical region of south Brazil. Ecología Austral 5:31-36.

Rodriguez-Mahecha, J. V., M. Alberico, F. Trujlllo, and J. Jorgenson. 2005. Libro rojo de los mamíferos de Colombia. Serie Libros Rojos de Especies Amenazadas de Colombia. Conservación Internacional Colombia, Instituto de Ciencias Naturales Universidad Nacional de Colombia, Ministerio del Medio Ambiente. Bogotá, Colombia.

Romero-Ruiz, M., A. Etter, A. Sarmiento, and K. Tansey. 2010. Spatial and temporal variability of fires in relation to ecosystems, land tenure and rainfall in savannas of northern South America. Global Change Biology 16:2013-2023.

Saldaña-Vázquez, R. A. 2014. Intrinsic and extrinsic factors affecting dietary specialization in Neotropical frugivorous bats. Mamalian Review 44:215-224.

Sampedro, A., C. Martínez, K. de la Ossa, Y. Otero, L. Santos, S. Osorio, and A. MERCADO. 2007. Nuevos registros de especies de murciélagos para el departamento de Sucre y algunos datos sobre su ecología en esta región colombiana. Caldasia 29:355-362.

Sánchez, F., J. Álvarez, C. Ariza, and A. Cadena. 2007. Bat assemblage structure in two dry forests of Colombia: Composition, species richness, and relative abundance. Mammalian Biology 72:82-92.

Sánchez-Cuervo, A. M., T. M. Aide, M. L. Clark, and A. Etter. 2012. Land Cover Change in Colombia: Surprising Forest Recovery Trends between 2001 and 2010. Plos One 7:1-14. 
Sánchez-Palomino, P., P. Rivas-Pava, and A. Cadena. 1993. Composición, abundancia y riqueza de especies de la comunidad de murciélagos en bosques de galería en la Serranía de la Macarena (Meta-Colombia). Caldasia 17:301-312.

Sarmiento, G. 1983. The savannas of tropical America. Pp. 254-288 en: Ecosystems of the World XIII. Tropical savannas (Bourliere, F., ed.). Elsevier. Amsterdam, Holanda.

Sarmiento, G. 1984. Ecology of Neotropical Savannas. Harvard university Press. Boston, U. S. A.

Sarmiento, G. 1994. Sabanas naturales: génesis y ecología. Pp. 17-55 en Sabanas Naturales de Colombia (Montes, S., ed.). Banco de Occidente. Cali, Colombia.

Schnitzler, H., C. F. Moss, and A. Denzinger. 2003. From spatial orientation to food acquisition in echocolating bats. Trends in Ecology and Evolution 18:386-394.

Simmons, N., AND R. S. Voss. 1998. The mammals of Paracou, French Guiana: a Neotropical lowland rainforest fauna. Part 1. Bats. Bulletin of the American Museum of Natural History 237:1-219.

Simmons, N. B. 2005. Order Chiroptera. Pp. 312-529 in Mammal species of the World: a taxonomic and geographic reference, Third Edition, Volume 1 (Wilson, D. E., and D. M. Reeder, eds.). Johns Hopkins University Press. Baltimore, U. S. A.

SOBERÓN, J., AND J. LLORENTE. 1993. The use of species accumulation functions for the prediction of species richness. Conservation Biology 7:480-488.

SuÁrez-Castro, A. F., and P. Sánchez-Palomino. 2011. Diversidad de mamíferos presentes en el bloque Cubiro y amenazas para su conservación. Pp. 277-290 in Mamíferos, Reptiles y ecosistemas del Bloque Cubiro (Casanare): Educación Ambiental para la Conservación (León-Sicard, T., P. Sánchez Palomino, and O. Vargas, eds.). Universidad Nacional de Colombia, Instituto de Estudios Ambientales, Departamento de Biología. Bogotá, Colombia.

Trujillo, W. F., And M. M. Henao-CÁrdenas. 2018. Riqueza florística y recambio de especies en la vertiente Orinoquense de los Andes, Colombia. Colombia forestal 21:18-33.

Trujillo, F. J., K. G. Garavito-Fonseca, M. V. Rodríguez-Maldonado, R. Combariza, L. Solano-Pérez, G. Pantoja, and J. P. Ávila-Guillen. 2011. Mamíferos de Casanare. Pp. 181-206 in Biodiversidad de Casanare: Ecosistemas Estratégicos del Departamento (Usma J. S., and F. Trujillo, eds.). Gobernación de CasanareWWF Colombia. Bogotá, Colombia.

Usma, J. S., AND F. Trujlllo. 2011. Biodiversidad del Casanare: Ecosistemas Estratégicos del Departamento. Gobernación de Casanare - WWF Colombia. Bogotá, Colombia.

Vela-Vargas, I. M., and J. Pérez-Torres. 2012. Murciélagos asociados a remanentes de bosque seco tropical en un sistema de ganadería extensiva (Colombia). Chiroptera Neotopical 18:1089-1100.

Velazco, P. M., and B. D. Patterson. 2013. Diversification of the Yellow-shouldered bats, Genus Sturnira (Chiroptera, Phyllostomidae), in the New World tropics. Molecular Phylogenetics and Evolution 68:683-98.

Voss, R. S., AND L. H. Emmons. 1996. Mammalian diversity in Neotropical lowland rainforest: a preliminary assessment. Bulletin of the American Museum of Natural History 230:1-115.
Voss, R. S., Lunde D. P., ANd N. Simmons. 2001. The mammals of Paracou, French Guiana: a Neotropical lowland rainforest fauna. Part 2. Nonvolant species. Bulletin of the American Museum of Natural History 263:1-263.

Wetterer, A. L., M. V. Rockman, And N. B. Simmons. 2000. Phylogeny of Phyllostomid Bats (Mammalia: Chiroptera): Data from diverse Morphological Systems, Sex Chromosomes, and Restriction Sites. Bulletin of the American Museum of Natural History 248:1-200.

Willott, S. J. 2001. Species accumulation curves and the measure of sampling effort. Journal of Applied Ecology 38:484-486.

Associated editor: Consuelo Lorenzo

Submitted: August 31, 2017; Reviewed: October 3, 2017;

Accepted: January 11, 2017; Published on line: January 25, 2018. 


\section{Appendix 1.}

List of collected specimens. ICN = Collection of Mammals "Alberto Cadena Garcia"of Instituto de Ciencias Naturales of Universidad Nacional de Colombia; IAvH = Instituto Alexander von Humboldt. RCFR = acronym including the collector number, regarded as temporary ID in the collections at ICN and $\mathrm{IAvH}$ pending a collection catalog number.

Artibeus planirostris ( $n=4$ : Provisional ICN\# RCFR-570, RCFR-571, Provisional IAvH\# RCFR-625, RCFR-631); Carollia brevicauda ( $n=10$ : Provisional ICN\# RCFR-403, RCFR404, RCFR-468, RCFR-469, RCFR-501, RCFR-524, RCFR-527, RCFR-533, RCFR-639; Provisional IAvH\# RCFR-429); Carollia perspicillata ( $n=1$ specimen: Provisional ICN\# RCFR550); Chiroderma villosum ( $n=2$ : Provisional ICN\# RCFR457, Provisional IAvH\# RCFR-389); Cyttarops alecto ( $n=3$ : Provisional ICN\#: RCFR-368, RCFR-400, Provisional IAvH\# RCFR-392); Dermanura bogotensis ( $n=6$ : Provisional ICN\#, RCFR-347, RCFR-354,RCFR-644; Provisional IAvH\# RCFR353, RCFR-558, RCFR-558 A), Dermanura gnoma ( $n=5$ : Provisional ICN\# RCFR-492, RCFR-508, RCFR-511, RCFR-538, RCFR -58 A); Desmodus rotundus ( $n=1$ specimen: Provisional ICN\# RCFR-467); Eptesicus brasiliensis ( $n=1$ specimen: Provisional ICN\# RCFR-432); Eptesicus diminutus ( $n=$ 1 specimen: Provisional ICN\# RCFR-470); Eptesicus furinalis (1 specimen: Provisional ICN\# RCFR-615); Eptesicus furinalis ( $n=2$ Provisional ICN\# RCFR-310, Provisional IAvH\# RCFR402); Glossophaga longirostris ( $n=1$ specimen Provisional ICN\# RCFR-474); Glossophaga soricina ( $n=3$ : Provisional ICN\# RCFR-422, RCFR 484, Provisional IAvH\# RCFR-348), Lampronycteris brachyotis ( $n=4$ : Provisional ICN\# RCFR450, RCFR-478, RCFR-495, Provisional IAvH\# RCFR-391); Lophostoma brasiliense ( $n=2$ : Provisional ICN\# RCFR-531, RCFR-535); Macrophyllum macrophyllum ( $n=1$ specimen: Provisional ICN\# RCFR-315); Mesophylla macconnelli $(n=11$ : Provisional ICN\# RCFR-327, RCFR-356, RCFR-465, RCFR-466, RCFR-529, RCFR-536, RCFR-620, RCFR-621, RCFR-623 Provisional IAvH\# RCFR-367, RCFR-559); Micronycteris megalotis ( $n=4$ : Provisional ICN\# RCFR-427, RCFR-494, RCFR-502, Provisional IAvH\# RCFR 638); Micronycteris microtis $(n=7$ : Provisional ICN\# RCFR-328, RCFR-428, RCFR-472, RCFR-628 Provisional IAvH\# RCFR-308, RCFR-415, RCFR-622); Micronycteris minuta ( $n=5$ : Provisional ICN\# RCFR-388, RCFR-444, RCFR-477, RCFR-645 Provisional IAvH\# RCFR-374); Mimon crenulatum ( $n=2$ : Provisional ICN\# RCFR-401 Provisional IAvH\# RCFR-395); Molossops temminckii ( $n=1$ specimen: Provisional ICN\# RCFR-471); Molossus molossus ( $n=2$ : Provisional ICN\# RCFR-436, Provisional IAvH\# RCFR-361); Myotis nigricans ( $n=25$ : Provisional ICN\# ICN RCFR-313, RCFR-317 A, RCFR-320, RCFR-330, RCFR-344, RCFR-411, RCFR-449, RCFR-416, RCFR-489, RCFR-490, RCFR-491, RCFR-493, RCFR496, RCFR-500, RCFR-506, RCFR-518, RCFR-528, RCFR-526, RCFR-540, RCFR-641, RCFR-642, Provisional IAvH\# RCFR317, RCFR-424, RCFR-434, RCFR-569); Myotis riparius ( $n=$ 22: Provisional ICN\# RCFR-318, RCFR-343, RCFR-350, RCFR377, RCFR-448, RCFR-513, RCFR-515, RCFR-520, RCFR-555, RCFR-611, RCFR-613, RCFR-643, Provisional IAvH\# RCFR-
316, RCFR-349, RCFR-352, RCFR-393, RCFR-548, RCFR-553, RCFR-565, RCFR-574, RCFR- 610, RCFR-640); Myotis sp. (1 specimen: Provisional ICN\# RCFR-419); Noctilio albiventris ( $n$ = 2: Provisional ICN\# RCFR-453; RCFR-454); Noctilio leporinus ( $n=2$ : Provisional ICN\# RCFR-455, RCFR-456); Peropteryx macrotis ( $n=3$ : Provisional ICN\# RCFR-311, RCFR-312, Provisional IAvH\# RCFR-303); Phyllostomus discolor ( $n=3$ : Provisional ICN\# RCFR-545, RCFR-547, Provisional IAvH\# RCFR556); Phyllostomus elongatus ( $n=4$ : Provisional ICN\# RCFR425, RCFR-486, RCFR-503, RCFR-630, RCFR-629); Phyllostomus hastatus ( $n=5$ : Provisional ICN\# RCFR-425 A, RCFR-426 A, RCFR-546, RCFR-549, Provisional IAvH\# RCFR-559); Platyrrhinus brachycephalus ( $n=4$ : Provisional ICN\# RCFR-306, RCFR-307, RCFR-480, Provisional IAvH\# RCFR-309 A); Platyrrhinus helleri ( $n=5$ : Provisional ICN\# RCFR-370, RCFR-373, RCFR-420, RCFR-537, Provisional IAvH\# RCFR-390, RCFR637); Rhinophylla pumilio ( $n=4$ : Provisional ICN\# RCFR-445, RCFR-446, RCFR-510, RCFR-530); Saccopteryx canescens ( $n=7$ : Provisional ICN\# RCFR-314, RCFR-430, RCFR-431, RCFR-447, RCFR-481, RCFR-517; Provisional IAvH\# RCFR319); Saccopteryx leptura ( $n=3$ : Provisional ICN\# RCFR-463, RCFR-464, RCFR-487); Sturnira lilium s.l. ( $n=2$ : Provisional IAvH\# RCFR-305, RCFR-412); Thyroptera lavali ( $n=1$ specimen: Provisional ICN\# RCFR-443); Tonatia saurophila ( $n=$ 2: Provisional ICN\# RCFR-426, Provisional IAvH\# RCFR-552); Trachops cirrhosus ( $n=9$ : Provisional ICN\# RCFR-433, RCFR479, RCFR-482, RCFR-483, RCFR-485, RCFR-509, RCFR-516, Provisional IAvH\# RCFR-397, RCFR-413); Trinycteris nicefori ( $n=6$ : Provisional ICN\# RCFR-387, RCFR-398, RCFR-405, RCFR-624, Provisional IAvH\# RCFR-371, RCFR-386); Uroderma bilobatum ( $n=5$ : Provisional ICN\# RCFR-300, RCFR301, RCFR-376, Provisional IAvH\# RCFR-375, RCFR-557); Uroderma magnirostrum ( $n=2$ : Provisional ICN\# RCFR-326, Provisional IAvH\# RCFR-551); Vampyressa thyone (Provisional IAvH\# RCFR-369, RCFR-372, RCFR-620); Vampyriscus bidens (1 specimen: Provisional ICN\# RCFR-473). 